\title{
Investigation of acute febrile illness outbreak- Asyaita and Dupti districts, Afar Region, Ethiopia, February 2011
}

\author{
Abyot Bekele Woyessa*, Worknesh Ayele, Abdi Ahimed, A Nega \\ From 17th International Symposium on HIV and Emerging Infectious Diseases (ISHEID) \\ Marseille, France. 23-25 May 2012
}

\begin{abstract}
Introduction
Acute Febrile Illnesses (AFIs) due to different etiologic agents are the most common causes of morbidity and mortality in developing tropical and subtropical countries. Afar region reported unidentified AFI outbreak on 10-Aug-2011. We investigated to identify etiologic agent, risk factors and to recommend prevention and control measures.
\end{abstract}

\section{Methods}

Unmatched case control study was employed. Study subjects (57 cases and 57 controls) were obtained and interviewed. Cases were defined as any person with fever $\geq$ $38.3 \mathrm{C}^{\circ}$, headache, pains in joints, muscles and back, anorexia and weakness. Medical records were reviewed and suspected AFI cases were identified from 07-Aug-2011 to 11-Sep-2011in Asyaita and Dupti districts. Active cases were searched house to house. Blood-samples, blood-serums and throat-swabs were collected and analyzed for heamoparasites, bacterial-pathogens, hemorrhagic fevers and respiratory viruses at national and CDC Kenya laboratories. Environmental scanning was performed. Odd-Ratio (OR) in $95 \%$ Confidence-Interval (CI) was calculated using Epi-Info version-3.5.1.

\section{Results}

A total of 12816 suspected AFI cases with no death were identified. Of the cases $9107(71 \%)$ were male and 3709 (29\%) were female. Attack-Rate (AR) was $8.7 \%$ (11.5\% in male and $5.4 \%$ in female) and $13.8 \%$ among $15-44$ agegroups. On bivariate analysis factors associated with illness were living with sick family member (OR: 2.8 ; $95 \%$ CI: 1.3 -

\footnotetext{
* Correspondence: sifanbashu@yahoo.com

Ethiopian Health and Nutrition Research Institute, Ethiopia, Addis Ababa, Ethiopia
}

\section{(O) BioMed Central}

(c) 2012 Woyessa et al; licensee BioMed Central Ltd. This is an Open Access article distributed under the terms of the Creative Commons Attribution License (http://creativecommons.org/licenses/by/2.0), which permits unrestricted use, distribution, and reproduction in any medium, provided the original work is properly cited.
Cite this article as: Woyessa et al:: Investigation of acute febrile illness outbreak- Asyaita and Dupti districts, Afar Region, Ethiopia, February 2011. Retrovirology 2012 9(Suppl 1):P46.

Submit your next manuscript to BioMed Central and take full advantage of:

- Convenient online submission

- Thorough peer review

- No space constraints or color figure charges

- Immediate publication on acceptance

- Inclusion in PubMed, CAS, Scopus and Google Scholar

- Research which is freely available for redistribution

Submit your manuscript at www.biomedcentral.com/submit
C Biomed Central 